\title{
Synthesis of indolo[3,2-b]carbazole-based new colorimetric receptor for anions: A unique color change for fluoride ions
}

\author{
Ajit Kumar Mahapatra*, Giridhari Hazra and Prithidipa Sahoo
}

\section{Preliminary Communication}

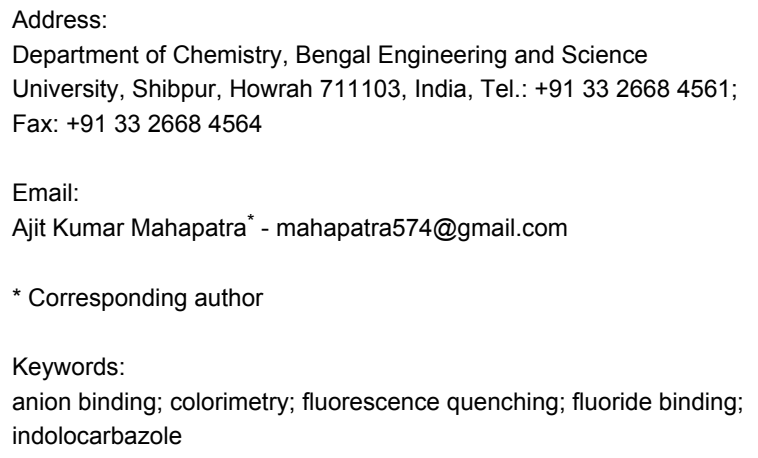

Beilstein Journal of Organic Chemistry 2010, 6, No. 12 doi:10.3762/bjoc.6.12

Received: 01 October 2009

Accepted: 30 January 2010

Published: 08 February 2010

Associate Editor: P. Skabara

(C) 2010 Mahapatra et al; licensee Beilstein-Institut. License and terms: see end of document.

\begin{abstract}
A novel indolocarbazole-based chemosensor 1 containing hydrogen bond donor moieties has been established as a selective colorimetric and fluorometric sensor for $\mathrm{F}^{-}$in $\mathrm{CH}_{3} \mathrm{CN} / \mathrm{H}_{2} \mathrm{O}(4: 1 \mathrm{v} / \mathrm{v})$. Upon the addition of a series of tetrabutylammonium salts to receptor 1 in aqueous $\mathrm{CH}_{3} \mathrm{CN}$, only when the counter ion was $\mathrm{F}^{-}$was a significant color change (from light violet to dark orange) observed.
\end{abstract}

\section{Introduction}

The design and synthesis of chromogenic receptors for biologically important and environmentally harmful anion pollutants has attracted considerable attention in supramolecular chemistry $[1,2]$. Most of the synthetic chemosensors generally involve covalent linking of an optical-signaling chromophoric fragment to a neutral anion receptor containing urea [3], thiourea [4], amide [5], phenol [6,7], or pyrrole [8] subunits, which can provide one or more H-bond donor sites for selective binding and sensing of certain anions, especially $\mathrm{F}^{-}, \mathrm{AcO}^{-}$, $\mathrm{H}_{2} \mathrm{PO}_{4}{ }^{-}$, etc. In particular, the selective sensing of fluoride has gained attention due to its significant role in clinical treatments e.g. dental care [9], osteoporosis [10] and for the detection of fluoride in bones as a result of over-accumulation [11]. This diversity of function, both beneficial and otherwise, makes the problem of fluoride ion detection of considerable interest. In this context, a colorimetric chemosensor is of particular interest due to its simplicity. Color changes that can be detected by the naked eye are widely used as signals for detection of anions without the need for any expensive equipment or even without the requirement of any equipment whatsoever $[12,13]$.

In the last few years, although some synthetic receptors have become available for fluoride ions [14-28], there is a paucity of reports on selective naked-eye chemosensors for fluoride [29-31]. Nitrophenyl, nitronaphthalene urea [32-34], naphthalene triphenyl-phosphonium [35], benzimidazolyl pyridine 
[36,37] and oxidized bis(indolyl)methane [38] as signal units for fluoride have been reported as chromogenic chemosensors, but a indolocarbazole ligand for the anion remains to be developed. Recently, Bhardwaj et al. reported a tripodal receptor [39] bearing catechol groups [40] for the chromogenic sensing of fluoride ions. Numerous bis(indolyl)methanes and their derivatives exhibit important biological activities [41]. Therefore, there has been great interest in the synthesis of bisindole compounds both naturally occurring and totally synthetic. As an extension of our work [42] on supramolecular chemistry, we now report a simple and new indolocarbazole-based molecular receptor 1 for the selective sensing of anions by investigating the effect of the addition of tetrabutylammonium salts $\left(\left[\mathrm{Bu}_{4} \mathrm{~N}\right]^{+} \mathrm{X}^{-}, \mathrm{X}=\mathrm{F}^{-}, \mathrm{Cl}^{-}, \mathrm{Br}^{-}, \mathrm{I}^{-}, \mathrm{AcO}^{-}, \mathrm{HSO}_{4}^{-}\right.$, and $\mathrm{H}_{2} \mathrm{PO}_{4}^{-}$). Receptor 1 (Figure 1) was particularly important as a chemosensor for fluoride owing to its noticeable color change in the presence of $\mathrm{F}^{-}$ions.

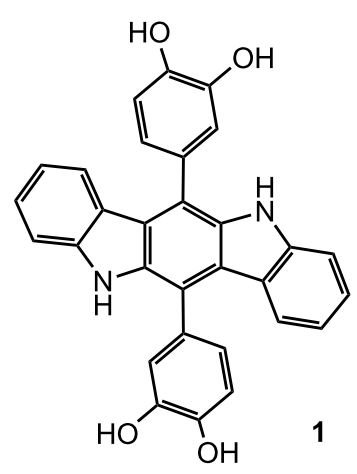

Figure 1: The structure of the indolocarbazole-based chemosensor 1.

\section{Results and Discussion}

\section{Synthesis}

Receptor 1 was synthesized [43,44] according to Scheme 1. Condensation of indole with 3,4-dihydroxybenzaldehyde by the reported procedure yielded intermediate 2 , which was found to

be unstable at room temperature. Subsequent heating of 2 in $\mathrm{CH}_{3} \mathrm{CN}$ in the presence of $\mathrm{I}_{2}$ for $45 \mathrm{~min}$ afforded the desired receptor $\mathbf{1}$ in $82 \%$ yield.

To look into the orientation of hydrogen bond donors around the carbazole motif, we optimized the structure by the AM1 method [45] (Figure 2). It is evident from Figure 2 that the two catechol units do not lie in the same plane as the carbazole unit. 


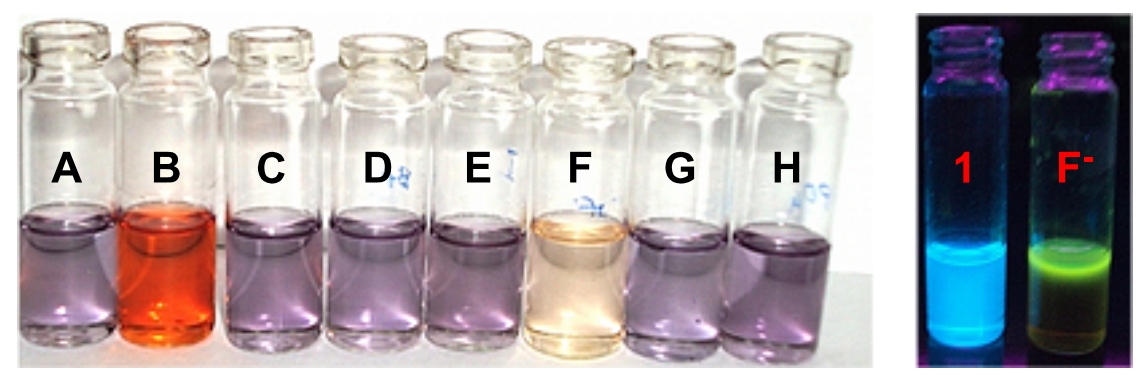

Figure 3: Color changes of receptor $1(A)\left(c=1.1 \times 10^{-4} \mathrm{M}\right)$ in $\mathrm{CH}_{3} \mathrm{CN} / \mathrm{H}_{2} \mathrm{O}(4: 1 \mathrm{v} / \mathrm{v})$ on addition of tetrabutylammonium salt $(\mathrm{TBAX}), \mathrm{X}=\mathrm{F}^{-}(\mathrm{B}), \mathrm{Cl}^{-}$ (C), $\mathrm{Br}^{-}(\mathrm{D}), \mathrm{I}^{-}(\mathrm{E}), \mathrm{AcO}^{-}(\mathrm{F}), \mathrm{HSO}_{4}^{-}(\mathrm{G})$, and $\mathrm{H}_{2} \mathrm{PO}_{4}^{-}(\mathrm{H})$ (left side); green fluorescence observed on addition of $\mathrm{F}^{-}$ion to receptor 1 (right side).

added to a solution of receptor $1\left(c=1.1 \times 10^{-4} \mathrm{M}\right)$ in the above noted solvent mixture.

In the naked-eye experiments, receptor $1\left(c=1.1 \times 10^{-4} \mathrm{M}\right)$ in $\mathrm{CH}_{3} \mathrm{CN} / \mathrm{H}_{2} \mathrm{O}(4: 1 \mathrm{v} / \mathrm{v})$ showed distinct color changes from light violet to dark orange and pale pink, respectively, in the presence of two equivalent amounts of TBAF and TBAOAc (Figure 3). In the fluorescence study, the sky blue color of $\mathbf{1}$ changed to a green color on the addition of TBAF. Importantly, the receptor was found to be insensitive to the addition of large excess of $\mathrm{Cl}^{-}, \mathrm{Br}^{-}, \mathrm{I}^{-}, \mathrm{HSO}_{4}^{-}$, and $\mathrm{H}_{2} \mathrm{PO}_{4}{ }^{-}$(even up to 100 equiv). The change in color was due to the deprotonation of phenolic $\mathrm{OH}$ groups followed by hydrogen bonding with fluoride ions. The strong hydrogen bonding to, or deprotonation/protonation of, the indolocarbazole moiety might modulate the electronic properties of chromophore [46] and give rise to significant color changes.

The interaction of receptor $1\left(c=1.1 \times 10^{-4} \mathrm{M}\right)$ with $\mathrm{F}^{-}$was investigated in aqueous $\mathrm{CH}_{3} \mathrm{CN}$ solvent in more detail by $\mathrm{UV}$-vis spectroscopic titration (Figure 4). Receptor 1 itself displays two absorption bands at 283 and $338 \mathrm{~nm}$ in $\mathrm{CH}_{3} \mathrm{CN} / \mathrm{H}_{2} \mathrm{O}(4: 1 \mathrm{v} / \mathrm{v})$. Upon the gradual addition of $\mathrm{F}^{-}$, the absorbance increases by different extents. On increasing the concentration of $\mathrm{F}^{-}$, two new absorption bands appear at 408 and $491 \mathrm{~nm}$, with the effect that the solution instantaneously changes color from light violet to dark orange. These two new bands can be ascribed to the deprotonated receptor. Figure 4 shows the $\mathrm{F}^{-}$-induced UV-vis spectral change of receptor 1 at different concentrations of fluoride ion in $\mathrm{CH}_{3} \mathrm{CN} / \mathrm{H}_{2} \mathrm{O}(4: 1 \mathrm{v} / \mathrm{v}$ ) (left side). A similar, but less remarkable spectral change, was observed upon addition of $\mathrm{AcO}^{-}$(right side) where a color change from light violet to light pink was achieved upon the addition of 10 equiv of $\mathrm{AcO}^{-}$.

The spectral behavior indicated that deprotonation of the phenolic $\mathrm{OH}$ as well as $\mathrm{NH}$ groups by $\mathrm{F}^{-}$(Scheme 2), and not hydrogen bonding to it, is responsible for the drastic color change [47], as a result of a change in the optical properties of chromogenic indolocarbazole skeleton. This is in agreement with the NMR titration data. Such deprotonation was related to
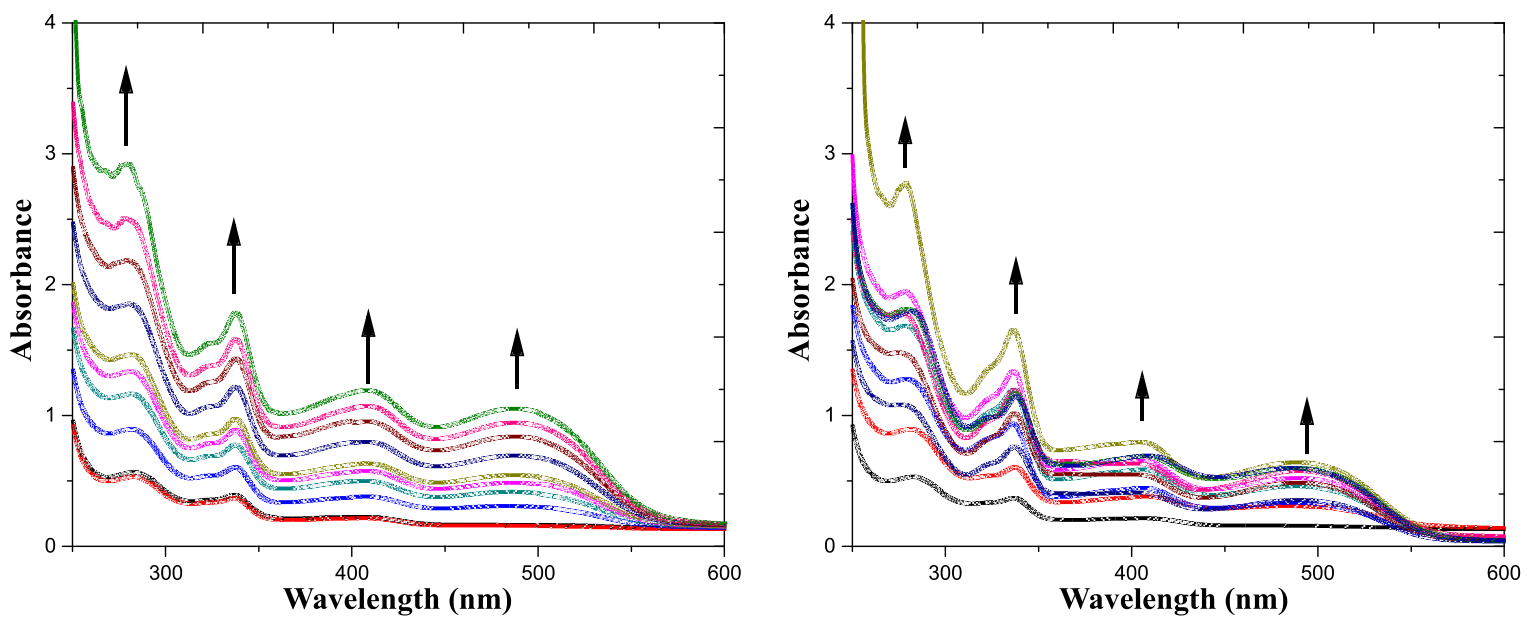

Figure 4: UV spectral change of receptor $1\left(c=1.1 \times 10^{-4} \mathrm{M}\right)$ upon gradual addition of $\left[\mathrm{Bu}_{4} \mathrm{~N}^{+} \mathrm{F}^{-}\right.$(left side) and $\left[\mathrm{Bu}_{4} \mathrm{~N}\right]^{+} \mathrm{AcO}^{-}$(right side) in $\mathrm{CH}_{3} \mathrm{CN}$ / $\mathrm{H}_{2} \mathrm{O}(4: 1 \mathrm{v} / \mathrm{v})\left(c=1.1 \times 10^{-4} \mathrm{M}\right)$ 


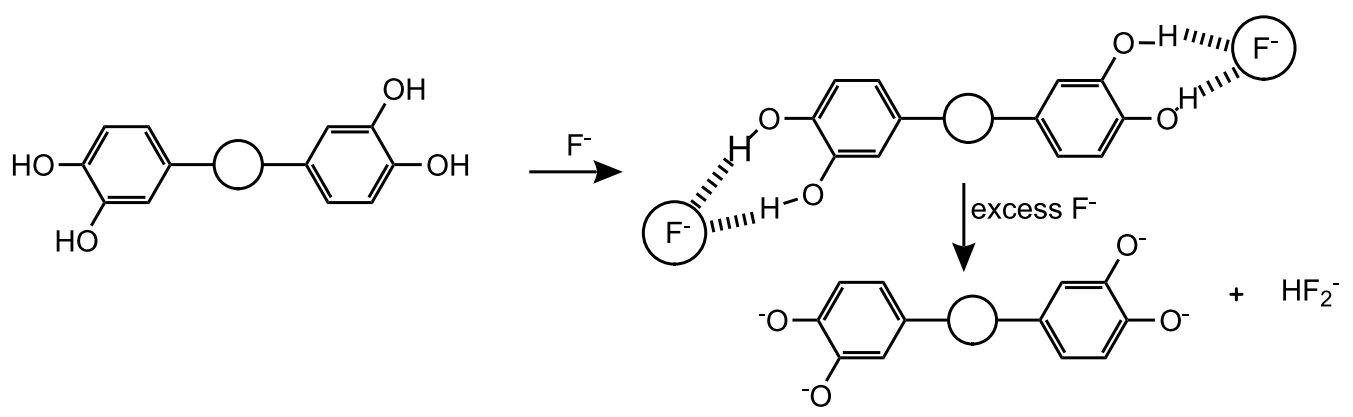

Scheme 2: Schematic representation (the circles represent the indolocarbazole moiety) of the two-step process leading to receptor deprotonation with basic fluoride anions.

the acidity of the H-bond donor site and the particular stability of the $\left[\mathrm{HF}_{2}\right]^{-}$ion. The stoichiometry of 1 with $\mathrm{F}^{-}$was determined to be 1:2 from the Job plot [48] (as shown in Figure 5).

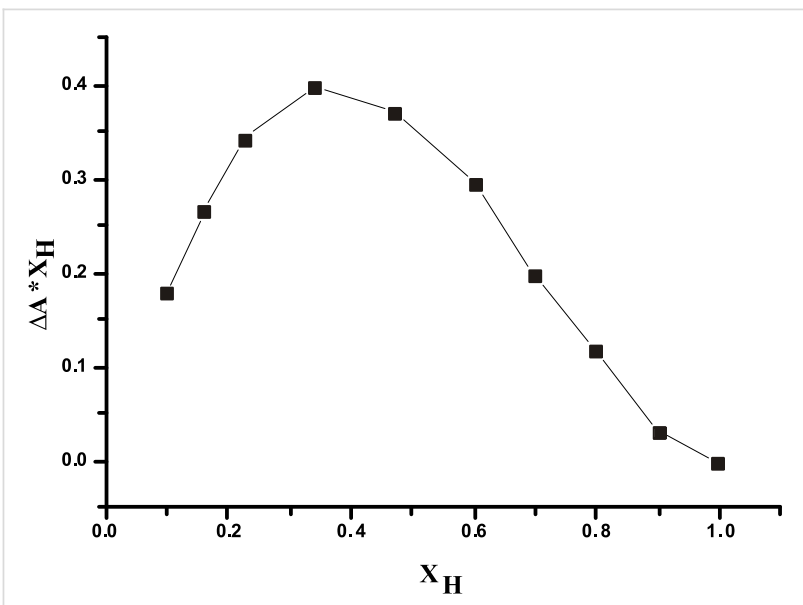

Figure 5: The Job plot of 1 with fluoride ion from UV method in $\mathrm{CH}_{3} \mathrm{CN} / \mathrm{H}_{2} \mathrm{O}(4: 1 \mathrm{v} / \mathrm{v})$.

Parallel investigations were carried out with a series of other anions $\left(\mathrm{Cl}^{-}, \mathrm{Br}^{-}, \mathrm{I}^{-}, \mathrm{AcO}^{-}, \mathrm{HSO}_{4}^{-}\right.$, and $\left.\mathrm{H}_{2} \mathrm{PO}_{4}{ }^{-}\right)$. Similar phenomena with negligible perturbations of $\mathrm{UV}$-vis absorption were observed with no noticeable change in color in the cases of $\mathrm{Cl}^{-}, \mathrm{Br}^{-}, \mathrm{I}^{-}, \mathrm{HSO}_{4}^{-}$, and $\mathrm{H}_{2} \mathrm{PO}_{4}^{-}$, even at levels of up to 100 equiv. Similar anion-sensing properties were also observed in the more polar solvent DMSO (all UV-vis spectra in supporting information).

Deprotonation of receptor 1 also took place with the basic anion $\mathrm{AcO}^{-}$and the development of a light pink color was observed after the addition of excess anion. No deprotonation took place in the presence of less basic anions such as $\mathrm{Cl}^{-}, \mathrm{Br}^{-}, \mathrm{I}^{-}, \mathrm{HSO}_{4}^{-}$, and $\mathrm{H}_{2} \mathrm{PO}_{4}{ }^{-}$. The receptor $\mathbf{1}$ is able to bind fluoride ion more strongly than other anions, since the catechol moiety is particularly effective in binding smaller anions. The deprotonation occurred at a slightly higher concentration of acetate than fluoride due to higher electronegativity, smaller size, and higher basicity of $\mathrm{F}^{-}$ions, which make them bind strongly with receptor 1 [49]. The binding constants $\left(K_{\mathrm{a}}\right)$ of receptor 1 (Table 1) with fluoride and other ions were determined by considering a hydrogen-bonded complex with the first two equivalents of anions in a 1:2 ratio of receptor and anion complex, and that, subsequently, the second equivalent of anion (addition of excess $\mathrm{F}^{-}$ion) abstracts a $\mathrm{HF}$ fragment to give $\left[\mathrm{HF}_{2}\right]^{-}$.

$\begin{aligned} & \text { Table 1: Association constants } \\ & \text { salts }\left(\mathrm{X}=\mathrm{F}^{-}, \mathrm{Cl}^{-}, \mathrm{Br}^{-}, \mathrm{I}^{-}, \mathrm{AcO}^{-}, \mathrm{HSO}_{4}^{-}, \text {and } \mathrm{H}_{2} \mathrm{PO}_{4}^{-}\right) \text {in } \mathrm{CH}_{3} \mathrm{CN} / \mathrm{H}_{2} \mathrm{O}\end{aligned}$
$\begin{aligned} & \text { (4:1 v/v) determined by UV-vis and fluorescence methods. } \\ & \text { Guests }\end{aligned}$
$\begin{array}{lll} & \mathrm{R} 1\left(\mathrm{Ka} \mathrm{M}_{\mathrm{a}} \mathrm{M}^{-1}\right) \\ & \text { UV-vis method } & \text { Fluorescence method } \\ \mathrm{F}^{-} & 3.62 \times 10^{4} & 8.21 \times 10^{4} \\ \mathrm{Cl}^{-} & 7.92 \times 10^{3} & 3.62 \times 10^{3} \\ \mathrm{Br}^{-} & 4.29 \times 10^{3} & 2.47 \times 10^{3} \\ \mathrm{I}^{-} & 4.13 \times 10^{3} & 2.27 \times 10^{3} \\ \mathrm{AcO}^{-} & 1.21 \times 10^{4} & 1.04 \times 10^{4} \\ \mathrm{HSO}_{4}^{-} & 1.14 \times 10^{3} & 2.25 \times 10^{3} \\ \mathrm{H}_{2} \mathrm{PO}_{4}^{-} & 1.32 \times 10^{3} & 6.65 \times 10^{3}\end{array}$

${ }^{a}$ All errors are $\pm 0.8 \%$.

A higher association constant was observed for fluoride ion than for other ions due to its strong hydrogen-bonding ability, small size, and better selectivity which resulted in a strong binding with receptor $\mathbf{1}$ [50].

\section{Fluorescence study}

Fluorescence spectroscopy studies were also carried out in order to evaluate the ability of $\mathbf{1}$ as a fluorescent anion sensor. Significant quenching of the fluorescence of $\mathbf{1}$ was observed upon addition of $\mathrm{F}^{-}$ions to the solution of $\mathbf{1}$ (Figure 6, left side). In comparison, other anions, with the exception of $\mathrm{AcO}^{-}$ (Figure 6, right side), hardly altered the emission of 1. A large 

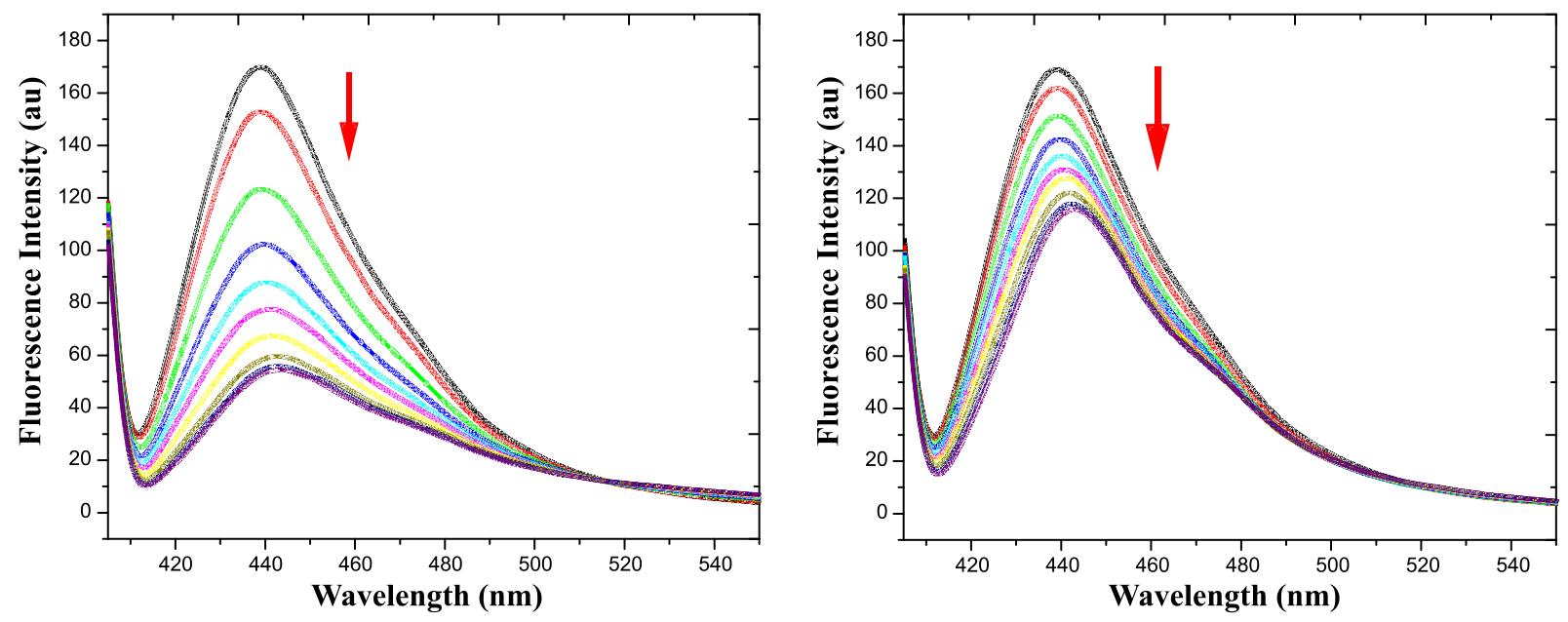

Figure 6: Fluorescence change of receptor $1\left(c=4.475 \times 10^{-5} \mathrm{M}\right)$ upon gradual addition of $\left[\mathrm{Bu}_{4} \mathrm{~N}^{+} \mathrm{F}^{-}\left(\right.\right.$left side) and $\left[\mathrm{Bu}{ }_{4} \mathrm{~N}\right]^{+} \mathrm{AcO}-($ right side $)$ in $\mathrm{CH}_{3} \mathrm{CN} / \mathrm{H}_{2} \mathrm{O}(4: 1 \mathrm{v} / \mathrm{v})\left(c=4.475 \times 10^{-5} \mathrm{M}\right)\left(\lambda_{\max }=443 \mathrm{~nm}\right)$.

quenching of intensity with respect to other anions (Figure 7 , right side) was observed at $439 \mathrm{~nm}$ upon the addition of 2.0 equiv of $\left[\mathrm{Bu}_{4} \mathrm{~N}\right]^{+} \mathrm{F}^{-}$. These results indicate that formation of hydrogen-bonded complex or deprotonation/protonation occurs by forming the anion of receptor $\mathbf{1}$; the excited state was modified considerably leading to the quenching of fluorescence. A commonly accepted mechanism for the quenching phenomenon involves an inversion between the strongly emissive $\pi \pi^{*}$ and the poorly emissive $n \pi^{*}$ states of this fluorophore. Such a quenching results from a hydrogen bond interaction of phenolic $\mathrm{OH}$ with anions, which leads to the stabilization of the $n \pi^{*}$ state with respect to the $\pi \pi^{*}$ state and a subsequent decrease in the fluorescence emission intensity [51].
Analogous investigation of fluorescence was carried out with other $\left[\mathrm{Bu}_{4} \mathrm{~N}\right]^{+} \mathrm{X}^{-}$salts $\left(\mathrm{X}=\mathrm{Cl}^{-}, \mathrm{Br}^{-}, \mathrm{I}^{-}, \mathrm{HSO}_{4}{ }^{-}\right.$, and $\left.\mathrm{H}_{2} \mathrm{PO}_{4}{ }^{-}\right)$. In all cases, only slight quenching occurs on the gradual addition of the anions $\left(\mathrm{Cl}^{-}, \mathrm{Br}^{-}, \mathrm{I}^{-}, \mathrm{HSO}_{4}{ }^{-}\right.$, and $\left.\mathrm{H}_{2} \mathrm{PO}_{4}{ }^{-}\right)$to receptor $\mathbf{1}$. The spectral variations observed for receptor $\mathbf{1}$ on titrating with different anions are given in the supplementary information.

\section{${ }^{1} \mathrm{H}$ NMR study}

The interaction of receptor 1 with $\mathrm{F}^{-}$was corroborated by ${ }^{1} \mathrm{H}$ NMR experiments carried out in DMSO- $d_{6}$ (1 has only limited solubility in $\left.\mathrm{CD}_{3} \mathrm{CN}\right)$. A partial ${ }^{1} \mathrm{H}$ NMR spectrum of receptor 1 is shown in Figure 8. It was found that the aromatic proton
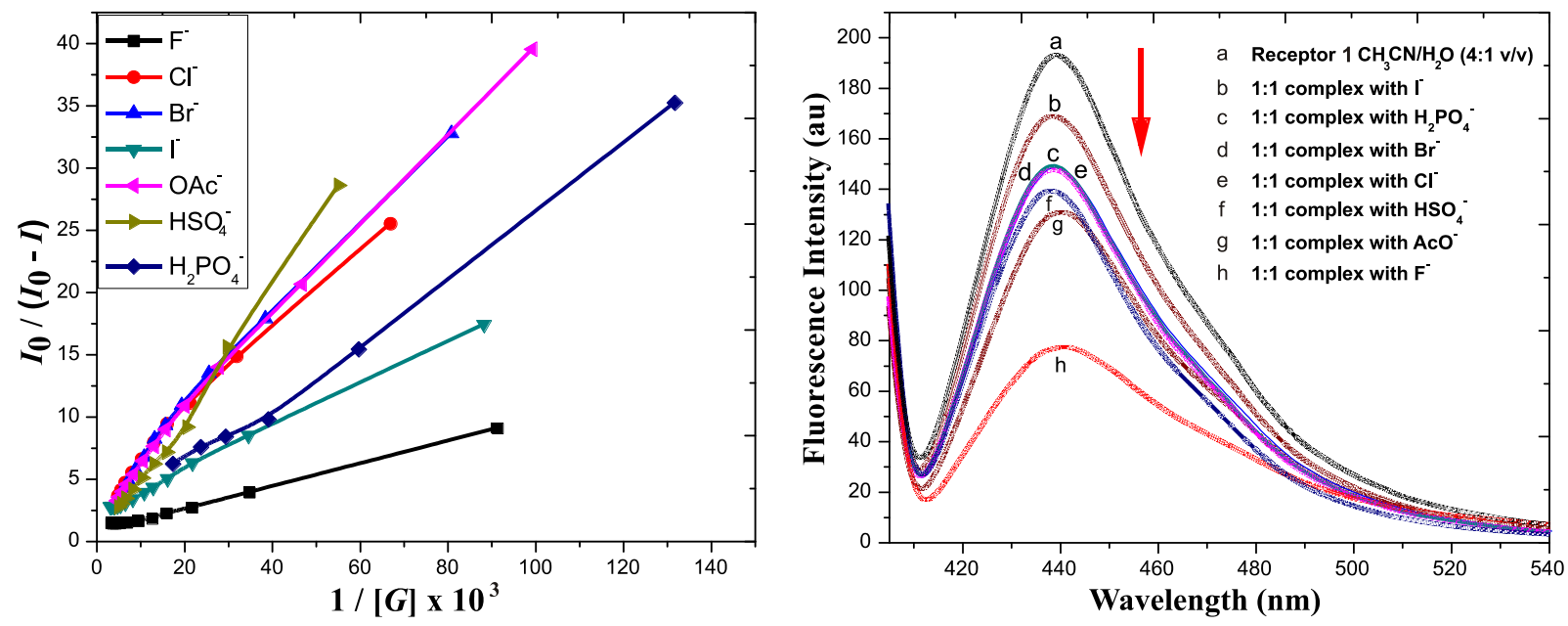

Figure 7: Binding constant calculation curves for receptor $1 \mathrm{vs} \mathrm{F}^{-}, \mathrm{Cl}^{-}, \mathrm{Br}^{-}, \mathrm{I}^{-}, \mathrm{AcO}^{-}, \mathrm{HSO}_{4}^{-}$, and $\mathrm{H}_{2} \mathrm{PO}_{4}^{-}$(left side); fluorescence spectra of 1 after addition of $1: 1$ equivalent of receptor and anions $\left(\mathrm{F}^{-}, \mathrm{Cl}^{-}, \mathrm{Br}^{-}, \mathrm{I}^{-}, \mathrm{AcO}^{-}, \mathrm{HSO}_{4}^{-}\right.$, and $\mathrm{H}_{2} \mathrm{PO}_{4}^{-}$) (right side). 
signals underwent upfield shifts with increasing $\mathrm{F}^{-}$concentration. In the presence of equivalent amounts of $\left[\mathrm{Bu}_{4} \mathrm{~N}\right]^{+} \mathrm{F}^{-}$, the signal for phenolic $\mathrm{OH}$ protons of $\mathbf{1}$ underwent large downfield shift $(\Delta \delta=1.34 \mathrm{ppm})$ and the proton signal was broadened. These observations further indicated that the first added $\mathrm{F}^{-}$ establishes an $\mathrm{H}$-bond interaction with the $\mathrm{OH}$ subunit of $\mathbf{1}$, while an excess of $\mathrm{F}^{-}$induces the deprotonation of the catechol moieties and $\mathrm{NH}$ proton, which brings electron density onto the $\pi$-conjugated framework through bond propagation, thus causing a shielding effect and inducing upfield shift of aromatic protons. The above mentioned results indicate that receptor 1 exhibits selective sensing for $\mathrm{F}^{-}\left(\mathrm{F}^{-}>\mathrm{AcO}^{-}>>\right.$other anions $)$in an appropriate solvent.

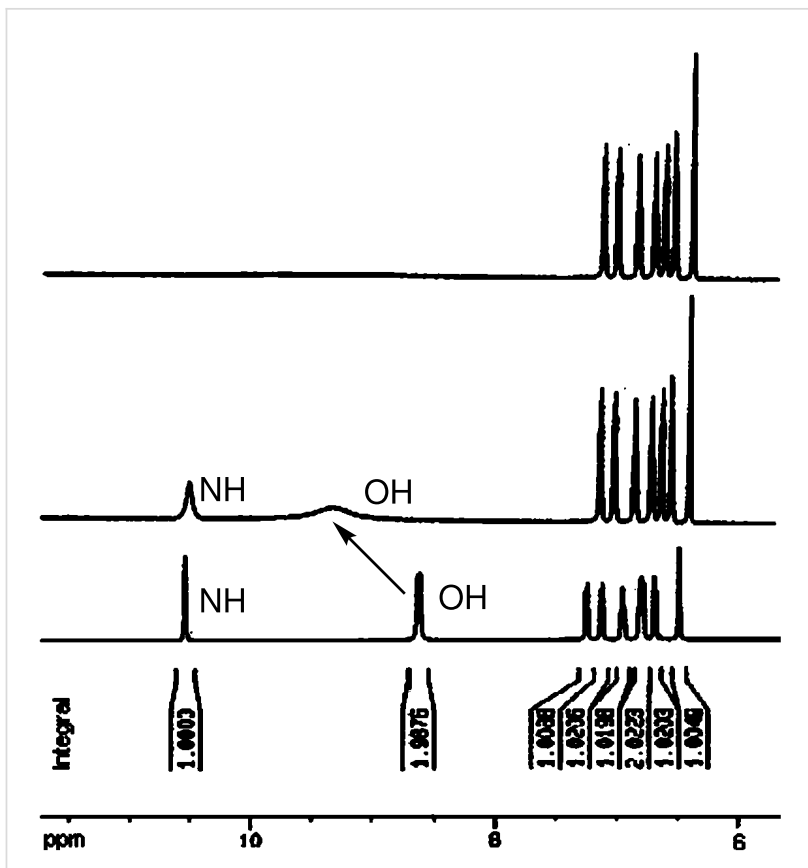

Figure 8: ${ }^{1} \mathrm{H}$ NMR spectra of receptor 1 (bottom), 1 with $\left[\mathrm{Bu}_{4} \mathrm{~N}\right]^{+} \mathrm{F}^{-} 1: 2$ [receptor 1:(Bu 4$\left.)^{+} F^{-}\right]$(middle) and excess $\left[\mathrm{Bu}_{4} \mathrm{~N}\right]^{+} \mathrm{F}^{-}$(top).

The fluoride- and acetate-induced deprotonation process is reversible as evidenced from the addition of $\mathrm{CH}_{3} \mathrm{OH}$. The addition of the polar protic solvent methanol results in a gradual decrease of absorbance in UV-vis studies. This is presumably because the presence of a relatively high amount of protic solvent disfavors the formation of the deprotonated receptor. However, in the water-acetonitrile system, no color changes were observed upon addition of organic bases such as triethylamine whilst the addition of excess $\left[\mathrm{Bu}_{4} \mathrm{~N}\right]^{+} \mathrm{OH}^{-}$can deprotonate receptor $\mathbf{1}$ and induce a color change.

\section{Conclusion}

In conclusion, a new colorimetric receptor $\mathbf{1}$ based on indolocarbazole was synthesized in high yield, which can form 1:2 complex with anions by multiple hydrogen-bonding interactions. Among the anions, only receptor 1 has higher selectivity for $\mathrm{F}^{-}$and leads to a distinct color change that can be observed by the naked eye. The binding results with a series of anions suggest that receptor 1 efficiently binds $\mathrm{F}^{-}$as established by UV-vis, fluorescence and ${ }^{1} \mathrm{H}$ NMR spectroscopic methods. As a colorimetric anion sensor, the indolocarbazole-based receptor 1 displayed highly selective coloration for $\mathrm{F}^{-}$ion even in the presence of other anions.

\section{Experimental \\ General details}

All reactions were carried out under a nitrogen atmosphere. Solvents were dried before use. Solvents for spectroscopic measurements were of spectroscopic or HPLC grade. The ${ }^{1} \mathrm{H}$ NMR spectra were recorded on a Bruker AM-500 spectrometer. The ${ }^{1} \mathrm{H}$ NMR chemical shift values are expressed in ppm $(\delta)$. UV-visible and fluorescence spectra measurements were performed on a JASCO V530 and a PerkinElmer LS-55 spectrofluorimeter, respectively. Receptor 1 and guest anions were dissolved in UV-grade acetonitrile and water (4:1 v/v). The corresponding absorbance values for receptor 1 were noted during titration and used for the determination of binding constant values. Binding constants were determined by using the expression $A_{0} / A-A_{0}=\left[\varepsilon_{\mathrm{M}} /\left(\varepsilon_{\mathrm{M}}-\varepsilon_{\mathrm{C}}\right)\right]\left(K_{\mathrm{a}}^{-1} C_{\mathrm{g}}^{-1}+1\right)$, where $\varepsilon_{\mathrm{M}}$ and $\varepsilon_{\mathrm{C}}$ are molar extinction coefficients for receptor and the hydrogen-bonding complex, respectively, at selected wavelengths, $A_{0}$ denotes the absorbance of the free receptors at the specific wavelength, and $C_{\mathrm{g}}$ is the concentration of $\left[\mathrm{Bu}_{4} \mathrm{~N}\right]^{+} \mathrm{X}^{-}\left(\mathrm{X}=\mathrm{F}^{-}, \mathrm{Cl}^{-}, \mathrm{Br}^{-}, \mathrm{I}^{-}, \mathrm{AcO}^{-}, \mathrm{HSO}_{4}{ }^{-}\right.$, and $\mathrm{H}_{2} \mathrm{PO}_{4}^{-}$ anions). The measured absorbance $A_{0} / A-A_{0}$ as a function of the inverse of the guest anion concentration fits a linear relationship, indicating a 1:2 complexation of the receptor and anions. The ratio of the intercepts to the slope was used to determine the binding constant $K_{\mathrm{a}}$.

Geometric optimization of their stable conformation of receptor 1 at the AM1 level was carried out using the minimal valence basis as STO 3G in ArgusLab 4.0.1 software suite. We have refrained from citing calculated total energy value, the calculation being for molecule only in the gas phase.

\section{Receptor 1}

3,3'-Bis(indolyl)-3,4-dihydroxyphenylmethane (2, 0.5 g, 1.41 $\mathrm{mmol})$ in a round-bottom flask containing dry acetonitrile (5 $\mathrm{mL}), \mathrm{I}_{2}(2 \mathrm{~mol} \%)$ was added and the mixture refluxed for 45 min. The solid obtained was filtered, dried and recrystallized from a mixture of DMF- $\mathrm{CHCl}_{3}$. Yield $82 \%$, mp $258{ }^{\circ} \mathrm{C} ;{ }^{1} \mathrm{H}$ NMR (500 MHz, DMSO- $d_{6}$ ): $\delta(\mathrm{ppm}) 10.53$ (s, 2H), 8.63 (bs, 4H), $7.24(\mathrm{~d}, J=8 \mathrm{~Hz}, 2 \mathrm{H}), 7.12(\mathrm{~d}, J=8 \mathrm{~Hz}, 2 \mathrm{H}), 6.94$ (t, $J=$ $7.5 \mathrm{~Hz}, 2 \mathrm{H}), 6.80$ (t, $J=7.5 \mathrm{~Hz}, 2 \mathrm{H}), 6.68(\mathrm{~d}, J=8 \mathrm{~Hz}, 2 \mathrm{H})$, 
$6.48(\mathrm{~d}, J=7.4 \mathrm{~Hz}, 2 \mathrm{H}), 6.43(\mathrm{~s}, 2 \mathrm{H}) ;{ }^{13} \mathrm{C} \mathrm{NMR}(125 \mathrm{MHz}$, DMSO- $d_{6}$ ): $\delta$ (ppm) 145.1, 143.9, 137.1 (for two carbon), 135.1 (for two carbon), 125.9, 120.4, 119.4, 118.59, 118.0, 115.4, 115.1, 11.0, 110.1; FTIR (KBr, cm $\left.{ }^{-1}\right)$ : 3472, 3430, 1521, 1457, 1262, 1224; $\mathrm{C}_{30} \mathrm{H}_{20} \mathrm{~N}_{2} \mathrm{O}_{4}$ (473.1496); Anal. Calcd C, 76.26; H, 4.27; N, 5.93; O, 13.54; found C, 76.35; H, 4.19; N, 5.73; O, 13.60; HRMS $\left(\mathrm{MH}^{+}+2\right): 475.21$.

\section{Supporting Information}

\section{Supporting Information File 1}

${ }^{13} \mathrm{C}$ NMR and mass spectra of the synthesized compound $\mathrm{R} 1$ and its $\mathrm{UV}-$ vis and fluorescence spectra in the presence of different anions $\left(\mathrm{Cl}^{-}, \mathrm{Br}^{-}, \mathrm{I}^{-}, \mathrm{HSO}_{4}^{-}\right.$, and $\left.\mathrm{H}_{2} \mathrm{PO}_{4}{ }^{-}\right)$. [http://www.beilstein-journals.org/bjoc/content/ supplementary/1860-5397-6-12-S1.pdf]

\section{Acknowledgements}

We thank DST [W.B. Government, project no. 694 (sanc.)/ST/ P/S\&T/6G-6/2007] for financial support. GH thanks CSIR, New Delhi for a fellowship during the course of work. Also thanks are due to Prof. S. P. Goswami for providing some instrumental facilities.

\section{References}

1. Martínez-Máñez, R.; Sancenón, F. Chem. Rev. 2003, 103, 4419-4476. doi:10.1021/cr010421e

2. Gale, P. A. Coord. Chem. Rev. 2003, 240, 191-221. doi:10.1016/S0010-8545(02)00258-8

3. Quinlan, E.; Matthews, S. E.; Gunnlaugsson, T. J. Org. Chem. 2007, 72, 7497-7503. doi:10.1021/jo070439a

4. Jose, D. A.; Kumar, D. K.; Ganguly, B.; Das, A. Org. Lett. 2004, 6, 3445-3448. doi:10.1021/ol048829w

5. Kim, H. J.; Lee, J. H.; Kim, T. H.; Lyoo, W. S.; Kim, D. W.; Lee, C.; Lee, T. S. J. Polym. Sci., Part A: Polym. Chem. 2007, 45, 1546-1556. doi:10.1002/pola.21923

6. Yu, M.; Lin, H.; Zhao, G.; Lin, H. J. Mol. Recognit. 2007, 20, 69-73. doi:10.1002/jmr.810

7. Luxami, V.; Kumar, S. Tetrahedron Lett. 2007, 48, 3083-3087. doi:10.1016/j.tetlet.2007.02.095

8. Ghosh, T.; Maiya, B. G. J. Chem. Sci. 2004, 116, 17-20. doi:10.1007/BF02708208

9. Kirk, K. L. Biochemistry of the Halogens and Inorganic Halides; Plenum Press: New York, 1991; p 58.

10. Kleerekoper, M. Endocrinol. Metab. Clin. North Am. 1998, 27 , 441-452. doi:10.1016/S0889-8529(05)70015-3

11. Geddes, C. D. Meas. Sci. Technol. 2001, 12, R53-R88. doi:10.1088/0957-0233/12/9/201

12. Schmidtchen, F. P.; Berger, M. Chem. Rev. 1997, 97, 1609-1646. doi:10.1021/cr9603845

13. Snowden, T. S.; Anslyn, E. V. Curr. Opin. Chem. Biol. 1999, 3, 740-746. doi:10.1016/S1367-5931(99)00034-4

14. Camiolo, S.; Gale, P. A. Chem. Commun. 2000, 1129-1130. doi:10.1039/b003229h
15. Lee, D. H.; Im, J. H.; Lee, J.-H.; Hong, J.-I. Tetrahedron Lett. 2002, 43, 9637-9640. doi:10.1016/S0040-4039(02)02443-7

16. Yun, S.; Ihm, H.; Kim, H. G.; Lee, C.-W.; Indrajit, B.; Oh, K. S.; Gong, Y. J.; Lee, J. W.; Yoon, J.; Lee, H. C.; Kim, K. S. J. Org. Chem. 2003, 68, 2467-2470. doi:10.1021/jo0263519

17. Luxami, V.; Sharma, N.; Kumar, S. Tetrahedron Lett. 2008, 49, 4265-4268. doi:10.1016/j.tetlet.2008.04.147

18. Saravanakumar, D.; Devaraj, S.; Iyyampillai, S.; Mohandoss, K.; Kandaswamy, M. Tetrahedron Lett. 2008, 49, 127-132. doi:10.1016/j.tetlet.2007.11.006

19. Black, C. B.; Andrioletti, B.; Try, A. C.; Ruiperez, C.; Sessler, J. L. J. Am. Chem. Soc. 1999, 121, 10438-10439. doi:10.1021/ja992579a

20. Ghosh, K.; Adhikari, S. Tetrahedron Lett. 2006, 47, 8165-8169. doi:10.1016/j.tetlet.2006.09.035

21. Lu, Q.-S.; Dong, L.; Zhang, J.; Li, J.; Jiang, L.; Huang, Y.; Qin, S.; Hu, C.-W.; Yu, X.-Q. Org. Lett. 2009, 11, 669-672. doi:10.1021/ol8027303

22. Kumar, S.; Luxami, V.; Kumar, A. Org. Lett. 2008, 10, 5549-5552. doi:10.1021/ol802352j

23. Kim, S. K.; Bok, J. H.; Bartsch, R. A.; Lee, J. Y.; Kim, J. S. Org. Lett. 2005, 7, 4839-4842. doi:10.1021/ol051609d

24. Coskun, A.; Akkaya, E. U. Tetrahedron Lett. 2004, 45, 4947-4949. doi:10.1016/j.tetlet.2004.04.130

25. Gunnlaugsson, T.; Kruger, P. E.; Jensen, P.; Tierney, J.; Paduka Ali, H. D.; Hussey, G. M. J. Org. Chem. 2005, 70, 10875-10878. doi:10.1021/jo0520487

26. Liu, C.; Qian, X.; Sun, G.; Zhao, L.; Li, Z. New J. Chem. 2008, 32, 472-476. doi:10.1039/b712554b

27. Singh, N.; Jang, D. O. Org. Lett. 2007, 9, 1991-1994. doi:10.1021/ol070592r

28. Linn, M. M.; Poncio, D. C.; Machado, V. G. Tetrahedron Lett. 2007, 48, 4547-4551. doi:10.1016/j.tetlet.2007.04.141

29. Boiocchi, M.; Boca, L. D.; Gómez, D. E.; Fabbrizzi, L.; Licchelli, M.; Monzani, E. J. Am. Chem. Soc. 2004, 126, 16507-16514. doi:10.1021/ja045936c

30. Miyaji, H.; Sessler, J. L. Angew. Chem., Int. Ed. 2001, 40, 154-157. doi:10.1002/1521-3773(20010105)40:1<154::AID-ANIE154>3.0.CO;2$\mathrm{G}$

31. Jose, D. A.; Kumar, D. K.; Ganguly, B.; Das, A. Org. Lett. 2004, 6, 3445-3448. doi:10.1021/ol048829w

32. Cho, E. J.; Ryu, B. J.; Lee, Y. J.; Nam, K. C. Org. Lett. 2005, 7, 2607-2609. doi:10.1021/ol0507470

33. Amendola, V.; Esteban-Gómez, D.; Fabbrizzi, L.; Licchelli, M. Acc. Chem. Res. 2006, 39, 343-353. doi:10.1021/ar050195।

34. Esteban-Gómez, D.; Fabbrizzi, L.; Licchelli, M. J. Org. Chem. 2005, 70, 5717-5720. doi:10.1021/jo050528s

35. Yeo, H. M.; Ryu, B. J.; Nam, K. C. Org. Lett. 2008, 10, 2931-2934. doi:10.1021/ol801153d

36. Chetia, B.; Iyer, P. K. Tetrahedron Lett. 2008, 49, 94-97. doi:10.1016/j.tetlet.2007.11.011

37. Duke, R. M.; Gunnlaugsson, T. Tetrahedron Lett. 2007, 48, 8043-8047. doi:10.1016/j.tetlet.2007.09.026

38. He, X.; Hu, S.; Liu, K.; Guo, Y.; Xu, J.; Shao, S. Org. Lett. 2006, 8, 333-336. doi:10.1021/ol052770r

39. Bhardwaj, V. K.; Hundal, M. S.; Hundal, G. Tetrahedron 2009, 65, 8556-8562. doi:10.1016/j.tet.2009.08.023

40. Winstanley, K. J.; Sayer, A. M.; Smith, D. K. Org. Biomol. Chem. 2006, 4, 1760-1767. doi:10.1039/b516433h

41. Bifulco, G.; Bruno, I.; Riccio, R.; Lavayre, J.; Bourdy, G. J. Nat. Prod. 1995, 58, 1254-1260. doi:10.1021/np50122a017 
42. Mahapatra, A. K.; Sahoo, P.; Goswami, S.; Chantrapromma, S.; Fun, H.-K. Tetrahedron Lett. 2009, 50, 89-92. doi:10.1016/j.tetlet.2008.10.095

43. Nagarajan, R.; Perumal, P. T. Chem. Lett. 2004, 33, 288-289. doi:10.1246/cl.2004.288

44. Deb, M. L.; Bhuyan, P. J. Synlett 2008, 325-328. doi:10.1055/s-2008-1032052

45. STO 3 G in ArgusLab 4.0.1; copyright (c) 1997-2004 Mark Thompson and Planaria Software LLC. http://www.arguslab.com. AM1 calculation was performed using minimal valence basis.

46. Hammud, H. H.; Ghannoum, A.; Masoud, M. S. Spectrochim. Acta, Part A 2006, 63, 255-265. doi:10.1016/j.saa.2005.04.020

47. Camiolo, S.; Gale, P. A.; Hursthouse, M. B.; Light, M. E. Org. Biomol. Chem. 2003, 1, 741-744. doi:10.1039/b210848h

48. Panzella, L.; Pezzella, A.; Arzillo, M.; Manini, P.; Napolitano, A.; d'Ischia, M. Tetrahedron 2009, 65, 2032-2036. doi:10.1016/j.tet.2009.01.003

49. Lee, D. H.; Lee, K. H.; Hong, J.-I. Org. Lett. 2001, 3, 5-8. doi:10.1021/ol006690t

50. Kato, R.; Nishizawa, S.; Hayashita, T.; Teramae, N. Tetrahedron Lett. 2001, 42, 5053-5056. doi:10.1016/S0040-4039(01)00916-9

51. Bazzicalupi, C.; Bencini, A.; Bianchi, A.; Borsari, L.; Danesi, A.; Giorgi, C.; Lodeiro, C.; Mariani, P.; Pina, F.; Santarelli, S.; Tamayo, A.; Valtancoli, B. Dalton Trans. 2006, 4000-4010. doi:10.1039/b603505a

\section{License and Terms}

This is an Open Access article under the terms of the Creative Commons Attribution License (http://creativecommons.org/licenses/by/2.0), which permits unrestricted use, distribution, and reproduction in any medium, provided the original work is properly cited.

The license is subject to the Beilstein Journal of Organic Chemistry terms and conditions:

(http://www.beilstein-journals.org/bjoc)

The definitive version of this article is the electronic one which can be found at: doi:10.3762/bjoc. 6.12 